\title{
War and peace in liberated North Korea: Soviet military administration and the creation of North Korean police force in 1945
}

\author{
Vasilii Lebedev* (1) \\ The University of Tokyo, Bunkyo-ku, Japan \\ *Corresponding author. Email: kutuzkin21@hanmail.net; rebedefu@g.ecc.u-tokyo.ac.jp
}

(Received 8 December 2020; revised 8 April 2021; accepted 9 April 2021)

\begin{abstract}
The North Korean police were arguably one of the most important organisations in liberated North Korea. It was instrumental in stabilising the North Korean society and eventually became one of the backbones for both the new North Korean regime and its military force. Scholars of different political orientation have attempted to reconstruct its early history leading to a set of views ranging from the "traditionalist" sovietisation concept to the more contemporary "revisionist" reconstruction that portrayed it as the cooperation of North Korean elites with the Soviet authorities in their bid for the control over the politics and the military, in which the Soviets merely played the supporting role. Drawing from the Soviet archival documents, this paper presents a third perspective, arguing that initially, the Soviet military administration in North Korea did not pursue any clear-cut political goals. On the contrary, the Soviet administration initially viewed North Koreans with distrust, making Soviets constantly conduct direct interventions to prevent North Korean radicals from using the police in their political struggle.
\end{abstract}

Key words: Communism; military occupation; North Korea; police; political struggle; USSR; WWII

In early November 1945, the temperature in Kosŏng county's police prison cell was rapidly falling as a group of nine Japanese and a Korean were taking what they believed to be their last breaths. Some three months earlier, none of them could probably believe that this would happen, but then on 15 August, the Emperor of Japan delivered his Jewel Voice Broadcast, while the Soviet forces were inflicting the Imperial Army in Manchuria and Northern Korea one blow after another. Administrative chaos ensued and before they knew it, new self-proclaimed Korean police units filled with vengeance against the servants of the old regime were knocking down their doors and dragging them to jail. A People's trial (inmin chaep'an) delivered a ruthless verdict: death penalty to the "national traitors" (minjok panyŏkcha). The gallows were built in the neighbouring Ch'orrwon county, where the execution was to be conducted publicly.

Just when it seemed that their fate was sealed, however, history took another turn. Right before the execution, a Soviet officer came with an order to stop the execution, transfer the Japanese to them and conduct a re-investigation concerning the arrested Korean. ${ }^{1}$ It is unclear as to what happened to the Japanese taken by the Soviets, but the Korean policemen hardly liked the unexpected intervention by their liberators.

The formation of North Korean police agencies and their connection to the Soviet military administration has long presented a subject of interest for many scholars of early North Korea. For a long

\footnotetext{
${ }^{1}$ NIKH 1990, p. 10.

(c) The Author(s), 2021. Published by Cambridge University Press. This is an Open Access article, distributed under the terms of the Creative Commons Attribution licence (http://creativecommons.org/licenses/by/4.0/), which permits unrestricted re-use, distribution, and reproduction in any medium, provided the original work is properly cited.
} 
time, the scholarly work was strongly influenced by both lack of archival materials and the politico-ideological confrontation under the Cold War. One of the major works on Korean history after the liberation involving documentary evidence, including documents of North Korean origin seized by the US Army during the Korean war, was two-volume research by Bruce Cummings. ${ }^{2}$ During the Cold War, there were other attempts to analyse the history of North Korea after the liberation, some of which used available Soviet sources that were mostly represented by official Soviet publications and memoirs of some participants. ${ }^{3}$ After the dissolution of the USSR, researchers gained unprecedented access to surviving participants of the events that produced studies containing some previously unknown details. ${ }^{4}$

The appearance of newly declassified Soviet documents, as well as further studies of the North Korean documents, helped produce a number of studies that shed light on the formation of the Korean People's Army (KPA), touching briefly on the issue of the North Korean police, ${ }^{5}$ support and resistance to the political processes in early North Korea, ${ }^{6}$ as well as on the role of the police and paramilitary units in the seizure of the political power by Kim Il-sung's group. ${ }^{7}$ The history of the North Korean police as an institution and its transformation, however, failed to receive proper attention from the scholars, and even studies that had chapters dedicated to the history of North Korean police agencies mostly presented it from a Kim Il-sung-centred point of view. ${ }^{8}$ On the other hand, some works, while rightfully stressing the Soviet presence in liberated North Korea as the most important factor in the North Korean revolution, along with some factual mistakes caused by the limitation of its sources, did not go into details as to the reason for Soviet military's actions during the early stages of occupation. ${ }^{9}$ Thus, the process of the North Korean police formation remains mostly unstudied.

Drawing from the discovered Soviet documents, the present study examines the formation of the North Korean police during the first several months after the liberation of North Korea. This paper argues that the North Korean police was created in the second half of 1945 under the direct supervision of Soviet military authorities. It challenges the arguments of some contemporary scholars that the North Korean police was created "because the Soviet authorities wanted to give the integrated police and security power to Kim II-Sung's group" and that after its creation they "gave authority over the security forces to Kim II-Sung." 10 I shall argue that despite being de-jure headed by Ch'oe Yong-gŏn, a former partisan and Kim Il-sung's comrade-in-arms, the police was initially created exclusively as a law enforcement force tasked to help overcome the political and economic chaos that in its turn was a by-product of the Soviet-Japanese war. The authority over the North Korean police was always in the hands of the Soviet military administration, and during the initial stage of occupation, Soviets did all they could to exclude the North Korean police from being used in political struggle. This paper also exposes several decades-old misconceptions such as the myth that while creating the police "Soviets selected 2,000 men whom they judged to be faithful followers of Communist ideology" 11 as well as a fake Soviet document nowadays mostly circulating in South Korean academic papers as a "proof" that Soviet military occupation pursued a specific political objective from the very beginning. ${ }^{12}$

\footnotetext{
${ }^{2}$ Cumings 1981, 1990.

${ }^{3}$ Ree 1989 .

${ }^{4}$ Chang Jun-ik 1991.

${ }^{5}$ Ki Gwang-sŏ 2004.

${ }^{6}$ Armstrong 2003.

${ }^{7}$ Kim Gwang-un 2003.

${ }^{8}$ Kim Sŏn-ho 2012, 2016.

${ }^{9}$ Lan'kov 2002.

${ }^{10}$ Kim 2018, p. 120.

${ }^{11}$ Chang Jun-ik 1991, p. 36; Kim 2018, p. 120; Kim Gwang-un 2003, p. 570; IMHMND 2004, p. 230.

${ }^{12}$ Kim Sŏn-ho 2020, pp. 178-79.
} 


\section{Soviet-Japanese war and liberation}

On 9 August 1945, after the declaration of war against Japan, the Soviet Red Army launched the Manchurian Strategic Offensive Operation. The same day as a part of this operation, a task force comprised of the units of the 1st Far-Eastern Front supported by the marines of the Soviet Pacific Fleet began military operations in Korea. The main mission was to support the Red Army's operations in Manchuria by cutting northern Korea's coastline from the Japanese mainland.

Immediately after the start of hostilities, the Soviet forces conducted a set of air raids targeting the Japanese military facilities in northern Korea, while shore parties of the Pacific fleet with the help of the units of the 25th Army, which would later be tasked with the occupation of North Korea, stormed the port towns and cities along the coastline of the Sea of Japan. Although some towns like Unggi (taken on 11 August) were captured almost without resistance, in better-fortified places like Rajin (12-13 August) and Ch'ongjin (13-16 August), the Soviet forces met heavy resistance from the Japanese troops which resulted in a series of bloody battles that involved air bombing, naval and heavy artillery bombardment and even an armoured train. ${ }^{13}$

In captured towns and cities, the Soviet military and Navy units created a temporary military administration named komendatura (commandant office). One of the first commandant offices was created by the Soviet Navy immediately after the battle of Rajin. ${ }^{14}$ The same measures were taken in Ch'ŏngjin after the Japanese forces there were defeated. In both cases, the commandant was chosen from the heads of the shore parties that led the assault and each commandant was tasked with mobilizing the local population to restore public order, protect banks, warehouses, etc., clear the streets from ruins that remained after the battle and the Soviet air raids, and arrest the remaining Japanese soldiers and undercover operatives.

In the case of Ch'ongjin, the latter task was of utmost importance for the Soviets because they believed it to be one of the bases for Japanese anti-Soviet espionage operations. Soviet counterintelligence even launched a special operation to apprehend Minozuma Junji, an important member of the Intelligence Department of Imperial Japanese Navy Headquarters who was believed to oversee the Japanese Naval intelligence activities towards the USSR in Korea. ${ }^{15}$

Even though the order to occupy entire northern Korea was not received by the Commander of the 25th Army until 17 August, ${ }^{16}$ Pyongyang was taken as late as 24 August, while the Soviet military presence on the 38th parallel was not established until the beginning of September 1945, the informational shockwaves spreading from Soviet military successes in northern Korea and Manchuria were strong enough to catalyse the collapse of the Japanese colonial system. Immediately after Japan officially announced its capitulation, an unprecedented vacuum of power emerged in Korea imbuing masses with enormous energy. The Soviet consul general in Seoul A. Polyanskii in his report noted that on 16 August, the people of Seoul had a demonstration "on which Koreans spoke and thanked the Red Army and comrade Stalin for liberating them from the Japanese yoke." A rumour spread that the Red Army was coming to Seoul. Some people organised a welcoming demonstration, while others took this opportunity to break in and pillage the homes of the Japanese people on the outskirts of Seoul. ${ }^{17}$ Seoul, however, was already outside of the Soviet-Japanese War's immediate influence as on the next day the Japanese police retaliated with force taking the situation back under control. ${ }^{18}$

The situation North of the $38^{\text {th }}$ parallel, on the other hand, was drastically different. The direct proximity of war practically paralysed the local administration. The absence of a capable united political force further sharpened contradictions between classes and political groups opening a way for an active, sometimes violent, struggle between organisations with different ideologies. Those who got the

\footnotetext{
${ }^{13}$ Glantz 2003, pp. 283-88.

${ }^{14}$ Ternovsky 1965, pp. 98-99.

${ }^{15}$ Khristoforov 2010, pp. 287-90.

${ }^{16}$ TsAMO F. 234, Op. 3213, D. 126, L. 131.

${ }^{17}$ RGASPI F. 17 , Op. 128 , D. 47 , L. $2-3$.

${ }^{18}$ Ibid. L. 4.
} 
upper hand in this struggle seized control over the local self-governing bodies, ${ }^{19}$ exercising their power through their own paramilitary organisations. These organisations had different names including "security force" (ch'iandae), "peacekeeping force" (poandae), "Red guard" (chŏgwidae), etc. They were used by the local committees to control all essential spheres of the population's life ranging from local governance, punishing criminals and "national traitors" as well as Japanese colonial officials, who failed to escape to the South in time, to organising economic activity such as grain redistribution, etc. ${ }^{20}$

In the eyes of the Soviets, however, these organisations were not effective in maintaining public order. On the contrary, their performance made Soviets doubt whether Koreans were really prepared to govern themselves. The first thing that struck the Soviets immediately after the end of hostilities was widespread looting that followed the retreat of the Japanese administration. One Soviet report stated that during the period immediately after the end of the war, the local population completely stripped the interior of all the passenger carriages rendering them unusable. ${ }^{21}$ Another report stated that all the valuables, equipment, materials, and property of ports were also plundered. ${ }^{22}$

The next problem was the political disunity of the groups that took power all over North Korea. The degree of autonomy was so high that it can be safely said that "each province [in North Korea] has established its own government." 23

What was worse, the Soviets could not even rely on local communists not in the least because Koreans were infamous for their factionalism. During the period before the liberation, both Koreans and the Comintern attempted to overcome these conflicts and create a Korean Communist Party several times. All these attempts suffered one failure after another, and even after the liberation, Korean communists in Seoul almost simultaneously created two groups claiming to be the only Communist Party of Korea. ${ }^{24}$

These groups immediately entered into a political confrontation in which various means of political struggle were implemented. The most remarkable example was the publication of a fake Soviet document titled "The Outline for the Creation of People's Government" (Inmin chŏnngbu surip yogang) ${ }^{25}$ under the name of the "Head of Military-Political Directorate of the Soviet Union lieutenant colonel Kŭrŭch'arŭ 그르차르." This document was reportedly first published in a South Korean newspaper Hyŏngmyŏng sinmun, though different historians give different dates of its publication. Some state that it was published in early September, ${ }^{26}$ "late September," ${ }^{27}$ some argue that it was printed on 4 October. $^{28}$

In this document, the "Soviet officer" laid out the vision for a new Korean government that appeared remarkably similar to one of the Korean left of the time. It contained such goals as "to persistently propose to the USSR, the US, Britain and China the creation of the power of workers and peasants," "to thoroughly eradicate the pro-Japanese elements," "to weed out the impure elements 不純分子," etc. This “Soviet document” became so popular that it was widely used in propaganda against the Korean communists back in the second half of the 1940s, ${ }^{29}$ and many South Korean researchers believe in its authenticity even now. ${ }^{30}$

\footnotetext{
${ }^{19}$ Due to the spontaneous nature of its formation process, there was a huge variety in the names of the new governing bodies. One of the most popular names were self-governing committee (chach'i wiwŏnhoe), political committee (chŏngch'i wiwŏnhoe) and people's committee (inmin wiwŏnhoe). Eventually the nomenclature was unified, and most local organisations were renamed into 'people's committees'. See Kim 2013, pp. 44-48.

${ }^{20}$ Kim 2013, pp. 44-45.

${ }^{21}$ AVPRF F. 0480, Op. 2, P. 2, D. 7, L. 99.

${ }^{22}$ AVPRF F. 0480, Op. 4, P. 14, D. 47, L. 124.

${ }^{23}$ Kim 2013, p. 49.

${ }^{24}$ Yi Ju-hwan 1998.

${ }^{25}$ Kim Gi-sŏk 1947, pp. 81-82.

${ }^{26}$ Kim Sŏn-ho 2020, p. 96.

${ }^{27}$ Cumings 1981, p. 387.

${ }^{28}$ Yi Wan-bŏm 1991, p. 170

${ }^{29}$ Kim Gi-sŏk 1947, pp. 81-82.

${ }^{30}$ Chŏn 1995; Kim Gwang-un 2018, p. 68; Kim Sŏn-ho, 2020.
} 
Even if we put aside the fact that the name "Kŭrŭch'arŭ" sounds more like a Korean impression on how the Russian name should sound rather than any real Russian surname (not to mention that in the ranks of the 25th Army, there was no political officer whose surname would at least slightly resemble the Korean "transcription"), it was literally impossible for any military serviceman to publish a document of such importance without the permission from his superiors.

Also, if it were true, then a copy of a document of such magnitude or at least a mention of one would appear in other Soviet documents of the period, however, the original has not yet been found. Instead in Russian archives, one can find a translated version of the article received by the Soviet command through Yi Yŏng, a leader of one of the two parallelly created Korean communist parties in Seoul, which undoubtedly led to a lot of raised eyebrows in the Soviet military command. According to the translation, the "Outline," printed by the "Seoul committee of the Korean Communist party," was dated 25 August and said to be first published by the "Local committee of the Communist Party of Southern Hamgyŏng province." ${ }^{\text {1 }}$

The political struggle concerning the control over the local branches did not immediately cease even after the formal creation of the North Korean Bureau of the Korean Communist Party in October 1945. The idea behind the establishment of the North Korean Bureau was to distance North Korean communists from the ongoing political struggle in Seoul, located outside of the sphere of control of the Soviet military. However, for example, the military commandant of Kanggye in his report on the situation in his county from 15 to 30 December 1945 stated that the local communist organisation was receiving its directives from the communist party organisation of Sinŭiju and Pyongyang. In order to prevent conflicts, the Soviet military commandant had to read the incoming directives from both organisations and give his own instructions based on the needs of the county. ${ }^{32}$

Another problem was the low theoretical and educational levels of the local communist cadres of North Korea. In some places, the Military Commandants observed that these people "only call themselves communists, but in fact, they have an ideology of kulaks ('village capitalists')." ${ }^{33}$ In some places, for a long time, there was no communist party organisation and the Soviets had to assist in creating one. Such was, for example, the case in Chasŏng where the first communist party organisation was created on 20 December, almost four months into the occupation. ${ }^{34}$

One of the most serious problems for the Soviets, however, was not even the lack of trustworthy cadres among Koreans but political violence and terrorism that widely spread around North Korea after the liberation. Throughout the first months after entering North Korea, the Soviets became witnesses of armed conflicts between different political groups such as the conflict in Haeju, Hwanghae province, when a group of presumably right-wing "police officers" committed an armed assault on the local People's committee in an attempt to oust a left-wing political group from its position of power. ${ }^{35}$

However, probably one of the most shocking cases of political terrorism for the Soviets was the assassination of Hyŏn Jun-hyŏk, one of the promising leaders of the North Korean communists in Pyongyang, which was committed by the members of the organisation called Taedongdan. Taedongdan a Pyongyang-based secret group that consisted of right-wing nationalists was allegedly found in 1943 by Yŏm Dong-jin.

Yŏm who received military education in Luoyang military school in China participated in the anti-Japanese resistance in Manchuria and was an associate of Sin Ik-hŭi, a member of "Provisional Government of Korea" and a known anti-Communist. It is said that during his years in China, he was captured by Chinese Communists and was "blinded through undergoing torture" during an interrogation, thus receiving the nickname "Blind General." ${ }^{36}$ Immediately after the liberation, this group began its struggle against communists and their sympathisers.

\footnotetext{
${ }^{31}$ TsAMO F. 172, Op. 614630, D. 5, P. 89-90.

${ }^{32}$ TsAMO F. Voyennoi komendatury provintsii Phenyan-pukto, Op. 536317, D. 19, L. 205.

${ }^{33}$ TsAMO F. USGASK, Op. 343254, D. 2, L. 128-128ob.

${ }^{34}$ TsAMO F. Voyennoi komendatury provintsii Phenyan-pukto, Op. 536317, D. 19, L. 169.

${ }^{35}$ IMHMND 2004, pp. 71-72.

${ }^{36} \mathrm{MBC}$ Bureau of Current Affairs and Production 2002, p. 27.
} 
Hyŏn Jun-hyŏk was assassinated on 3 September 1945, barely a week after the 25th Army command arrived in Pyongyang. That day he and Cho Man-sik, the leader of the People's Committee of Pyongyang, were returning in a truck after visiting the 25th Army HQ. When the car slowed down on one of the streets, a member of the Taedongdan Paek Kwan-ok, armed with a pistol, ran towards the car and shot Hyŏn. ${ }^{37}$ Immediately after that, the group escaped to Seoul. In November 1945, it adopted a new name, "White Shirts Society (Paegŭisa)," and with the help of Sin Ik-hŭi, who returned to South Korea after the liberation, resumed its activities towards North Korea. ${ }^{38}$

It is worth mentioning that, as the evidence suggests, in the case of liberated Korea, the "white terror" historically preceded what would later become the "red terror." Although later the poles will start gradually shifting, the spread of anti-communist terrorist activity in late 1945 made the creation of a unified security force the top priority for both North Koreans as well as the Soviets.

Naturally, all these factors did not present Koreans as allies capable of managing North Korea, thus contrary to what some of the abovementioned historians argue, the option of indirect control or wide cooperation with North Korean political forces, including communists, was unavailable to Soviets from the very beginning of the occupation even if they were inclined to do so.

\section{Establishment of commandant offices}

The political situation and the overall state of public order in North Korea made it clear for the Soviet military command that working with the existing organisations in terms of assisting the military occupation was out of the question. The order of the 1st Far Eastern Front Command to the Command of the $25^{\text {th }}$ Army on the occupation only stated that its units were to move into northern Korea on 18 August and take control over the territory of Korea above the 38th parallel. ${ }^{39}$ The absence of concrete timeframes of the occupation meant that the 25th Army's command had to come up with new measures for preserving law and order while waiting for more concrete directives from the superiors.

Naturally, the first and foremost mission of the Soviet forces in North Korea was to accept the capitulation of the Japanese army units. This task, however, was much more complex than the simple disarmament of the Japanese soldiers, since it also implied taking control over all sorts of equipment, including weapons, vehicles, factories, power plants, etc., some of which the Soviets saw as war trophies to be transported to the USSR to help repair their war-damaged economy. In turn, this required the creation of a wide network of Soviet military administration agencies throughout the region that would work with the local population and conduct central military administration policies.

Starting from late August 1945, the Command of the 25th Army began the creation of military administrative agencies named komendatura (Military Commandant Office), a standard name for Russian and Soviet military representative agencies which was also used in other places where the Red Army had to make long-term contact with the local population, such as Poland, Germany, etc. The jurisdiction of the 25th Army's komendaturas was regulated by a set of instructions called "Concise Manual for a Military Commandant." The copy of the manual discovered in Russian archives was issued in late August by the Chief of Staff of the 25 th Army V. A. Pen'kovskii ${ }^{40}$ and was composed of three parts, namely organisational, economic and political/cultural activities. Though the preface of the copy states that they were intended for use by Soviet komendaturas in Manchuria, it can be safely assumed that they were used in North Korea as well.

According to the manual, the main mission of these commandant offices was twofold. Their first task was to "guarantee normal life of a settlement by providing internal order and security for people and property (both private and common)." ${ }^{41}$ The authorised measures included confiscation of all

\footnotetext{
${ }^{37}$ Han 2002; MBC Bureau of Current Affairs and Production 2002, p. 186; TsAMO F. USGASK, Op. 433847, D. 1 , L. 47.

${ }^{38}$ To Jin-sun 1997, pp. 77-78.

${ }^{39}$ TsAMO F. 234, Op. 3213, D. 126, L. 131-132.

${ }^{40}$ Chistyakov 1975, p. 292.

${ }^{41}$ TsAMO F. 32, Op. 11318, D. 196, L. 94.
} 
weapons held by the local population, weeding out remaining enemy agents, providing fire safety, clearing roads from enemy mines, protecting the town from enemy troops that did not yet surrender, etc. All police officers and members of armed organisations were to register at the local komendatura and hand over all weapons and ammunition.

Komendaturas did not intend to replace local police or paramilitary organisations that briefly took the role of a peacekeeping force but rather attempted to put them under control through a network of confidantes which they called aktiv (activists). These activists were chosen from the locals who could help with conducting explanatory work, weeding out elements hostile to the Red Army, organising works to restore the local economy, etc. They were also to become the Korean faces and voices of the Soviet military government at the local level and as such were to be chosen carefully. The process of selection involved running a full background check on a candidate in close cooperation with the SMERSH (Soviet military counterintelligence). ${ }^{42}$ The preference was given to those who had been politically repressed by the Japanese or to democratic activists who did not cooperate with the colonial regime. Special preference was also given to former guerrilla fighters who provided active assistance to the Red Army during the war.

The second task of the Military Commandants, crucial for the stability of Soviet operation in North Korea, was the control over the units of the Red Army itself. Despite active propaganda among the Red Army soldiers that they were entering Korea as liberators and should behave as such, their commanders had no illusions about the number of problems their soldiers can create. The manual clearly stated that one of the commandant's primary duties was to keep "unnecessary" interaction between Red Army soldiers and the local population to a minimum. To keep the locally stationed Red Army units in line and to prevent misbehaviour and criminal activity, commandants were given the right to deal with suspected criminals among soldiers. ${ }^{43}$

The commandant offices had a strict chain of command. Komendaturas were set up on three levels. The highest ones were provincial komendaturas, which were usually located in provincial capitals, and city-level komendaturas, which exercised control over the biggest port and industrial centres of North Korea. Below them were county-level komendaturas which covered the most territory of North Korea. Though the number of komendaturas varied, there were about 6 provincial, 85 county-level and 7 citylevel komendaturas covering all territory of the Korean peninsula north of the 38th parallel. The staff of a provincial komendatura normally included the military commandant himself, hid deputy for military training who was charged with keeping the local soldiers busy, assistants, instructors, cook, deputy secretary, an interpreter, etc., twenty-two men in total who commanded an infantry platoon. County-level commandant offices had a skeleton crew of six men plus an infantry platoon which, after the situation stabilised, was changed into a squad. ${ }^{44}$

The scope of the komendaturas' responsibilities is perfectly illustrated by the contents of the reports that a lower-level office had to regularly (usually once every 15 days) file to a higher level komendatura which in turn reported to the Military Council of the 25th Army. Reports usually began with the description of the commandant office's staff, stressing its shortages. Due to the lack of professional cadres, most komendaturas, especially at the beginning of the occupation, suffered a severe shortage of interpreters, clerks and, most importantly, soldiers and officers for the commandant office's patrol unit. It was followed by a report on the activities of the given komendatura including the participation in the restoration and control over the economic activity in the region. It also included information on the political and economic situation in the region and a report on the progress of the tasks given by the 25th Army's command.

Along with this information, reports also included a section concerning the state of public security in the region. Here Soviet military commandants explained the state of public security and their work with the local police agencies including the situation with the police's weapons, its size and problems.

\footnotetext{
${ }^{42}$ Ibid. L. 100.

${ }^{43}$ Ibid. L. 94.

${ }^{44}$ AVPRF F. 0480 , Op. 4, P. 14 , D. 46 , L. 4-5.
} 
This section also included information on the criminal activity in the region, prison population and on "hostile activities" of the local population towards the Red Army and local government agencies. Such information was usually obtained either from the head of the police office himself or through the commandant office-hired "activists" and was highly detailed. For example, the military commandant of Kusŏng county at the end of 1945 described numerous instances of political struggle between members of the Democratic party, a moderate leftist nationalist party officially established on 3 November 1945 with the Soviet permission and headed by Cho Mansik ${ }^{45}$ and the local communists that included deliberate instigation of enmity against each other, threats of physical elimination, etc. The magnitude of problems forced him to take actions against both sides that ranged from official meetings with members of the parties to arrests and short-term incarceration. ${ }^{46}$

Finally, almost every report had a part concerning the moral state of the Red Army units in a given region, such as the report on military training and the work of local Komsomol (Communist Youth) and Soviet Communist party organisations which were intended to occupy soldiers preventing them from engaging in criminal activity. Local commandants also kept statistics of acts of "immoral behaviour" committed by Soviet soldiers. These acts of "improper behaviour" ranged from alcoholism, indiscipline, failure to salute one's superior officer, sleeping while on duty and other actions that are contrary to established Red Army ethics, to crimes such as fencing of stolen goods through local Koreans, armed robbery, rape, etc. ${ }^{47}$

The creation of the commandant offices and their direct involvement in the affairs of the local police coincided with the clarification of the Soviet policy in Korea by the High Command of the Red Army. On 20 September, Stalin issued a directive to the Military Council of the 25th Army to "assist the establishment of a bourgeois-democratic power on a base of a wide bloc of all anti-Japanese democratic parties and organisations" and forbade the installation of Soviet system in Korea. ${ }^{48}$ Stalin's directive was soon implemented in the form of Order No. 7 of the 25th Army which was approved and published on 10 October. The order instructed Soviet commandants to disarm and disband all military and paramilitary groups including the local police, which demonstrated the degree of distrust the Soviets had towards the existing law enforcement organisations.

Order No. 7 can also be seen as the official starting point in the history of the new North Korean police force. It stated: "For the purpose of upholding public order among the civilian population, [I order to] allow Provisional Provincial Committees to create police. Its size is to be set in coordination with the Soviet military command." 49

The disbandment of Korean paramilitary organisations and the reorganisation of police units started promptly. During the first couple of weeks, large quantities of ammunition, along with thousands of weapons, were confiscated by the Soviet military authorities. For example, after komendatura was established in a town of Kanggye, Northern P'yŏngan province, the military commandant reported the confiscation of over a thousand units of various weaponry including rifles, heavy machine guns, all kinds of pistols, swords, hand grenades from a left-wing nationalist youth organisation called "the Red Guard" and from former colonial police units and civilians. ${ }^{50}$ Some komendaturas were even reinforced with SMERSH NKVD (People's Commissariat of Internal Affairs) operatives tasked with apprehending former Japanese officials to prevent undercover resistance and sabotage. ${ }^{51}$ In some places like Ryong'amp'o, the police were "radically reorganised" by the local military commandant who ordered the local government to replace the head of the police, his deputies and assistants leaving 170 officers out of 229 and stripping them of all means of self-defence including melee weapons. ${ }^{52}$ The

\footnotetext{
${ }^{45}$ TsAMO F. USGASK. Op. 537792, D. 1, L. 4.

${ }^{46}$ TsAMO F. Voyennoi komendatury provintsii Phenyan-pukto, Op. 536317, D. 19, L. 80.

${ }^{47}$ TsAMO F. USGASK, Op. 102038, D. 2, L. 93-95.

${ }^{48}$ TsAMO F. 148 , Op. 3763 , D. 111, L. 92-93.

${ }^{49}$ TsAMO F. 234 , Op. 3213, D. 524, L. $160-162$.

${ }^{50}$ TsAMO F. Voyennoi komendatury provintsii Phenyan-pukto, Op. 536317, D. 19, L. 11-12.

${ }^{51}$ Ibid. L. 29-30.

${ }^{52}$ Ibid. L. 29-30.
} 
process was not smooth, however, and some organisations managed to stay out of Soviet military commandants' sight for months. For example, a paramilitary organisation "Self-protection squad" Chawidae connected with the North Korean Labour Union was only discovered and disbanded as late as February $1946 .^{53}$

\section{Creation of the Police Department of North Korea}

The creation of the commandant offices, the subsequent increase in the 25th Army's workload, and the situation with public order in North Korea necessitated the creation of a structure that would concentrate control over all spheres of life in North Korea in the hands of the Soviet military administration. In mid-October 1945, the 25th Army's command asked Moscow to allow the formation of a supporting structure for the occupation of North Korea. On 17 October 1945, Deputy People's Commissar for Foreign Affairs S. Lozovskii wrote a draft of a directive concerning the creation of a Civil Administration to assist Soviet operations in North Korea. This draft was first presented and discussed with the heads of the two main bodies directly responsible for the occupation of North Korea, namely the General Headquarters and the Main Political Administration of the Red Army and then sent for finalisation and approval to the People's Commissar for Foreign Affairs V. Molotov. ${ }^{54}$ This directive was the first document that outlined the organisational structure of the Soviet Civil Administration that, unlike the agencies of military administration such as komendaturas, would also include local Koreans.

The directive was soon finalised and, in early November 1945, a new structure consisting of ten departments was created under the direct control of the 25th Army Commander (Departamenty pri komanduyuschem 25-i Armiei). These were departments of Industry, Transport, Land and Forest, Finance, Communications, Trade, Education, Healthcare, Justice, and Police. However, even though the departments were staffed and formally headed by Koreans, as we will see in the case with the Police Department, they were de facto headed by a Soviet Military Representative. The departments were created with a mission to provide "more operative control over the economic and political life of North Korea, and to coordinate the actions of the local organs of power." ster the effectiveness of the new structure, the Soviet military command appointed Romanenko Deputy Commander for Civil Administration (zamestitel' komanduyuschego po grazhdanskoy administratsii) giving him a staff of fifty officers who were to control and direct the actions of the departments. ${ }^{56}$

The Police Department of North Korea (Departament politsii Severnoi Korei; PDNK) was created as a part of the Soviet Civil Administration in early November 1945 with the signing of a document called "The basic provisions on the organisation and work of the police organs in North Korea (Osnovniye polozheniya ob organisatsii i rabote politseiskikh organov v Severnoi Koree)." It described the structure and functions of the new organisation. ${ }^{57}$ Some South Korean historians emphasise the figure of Ch'oe Yong-gŏn, the appointed head of the PDNK who was the only member of Kim Il-sung's group and anti-Japanese Manchurian partisans to hold an official post in the Soviet Civil Administration during the initial period of occupation. This brought forth a theory stating that Ch'oe was able to get this post because the members of the Anti-Japanese partisan movement, based on their experience as partisans, "could not yield or allow interference [of other powers], or even share the 'right for an army' (kunkwŏn; 軍權)." ${ }^{58}$ The first two paragraphs of this document, however, leave no doubt as to who controlled the activities of the PDNK, and as such deserves to be quoted in full.

\footnotetext{
${ }^{53}$ TsAMO F. USGASK, Op. 102038, D. 1, L. 12-13.

${ }^{54}$ AVPRF F. 0102 , Op. 1, P. 1, D. 5, L. 7-8.

${ }^{55}$ AVPRF F. 0480 , Op. 4, P. 14 , D. 46 , L. 6.

${ }^{56}$ Ibid. L. 6-8.

${ }^{57}$ TsAMO F. USGASK, Op. 343253, D. 3, L. 28-32.

${ }^{58}$ Kim Gwang-un 2003, p. 259.
} 
(1) In order to preserve social order and tranquillity, as well as to fight criminal activity among the civil population of North Korea, in all provincial, county, township and city committees a police force is organised, which is controlled by the Department of Police of North Korea and, at the same time, is subordinate to the corresponding people's committees.

(2) The Department of Police of North Korea works in accordance with the directives of the Soviet military command, who has its military representative in the department. The head of the department is obliged to execute all orders and directives of the Soviet military representative. ${ }^{59}$

All the de facto power in the PDNK was in the hands of Colonel Nikolay Zagruzin, who was appointed "Military representative at the Police Department (Voyenniy predstavitel' departamenta politsii)." Zagruzin, a 40-year-old Red Army Colonel, was a decorated Soviet officer who participated in the Great Patriotic War from the very beginning as a part of the North-Eastern Steppe Front (later the 2nd Ukrainian Front). After the war in Europe, he was sent to the Far East to fight the Japanese. He led a vanguard shore party during the Battle of Ch'ŏngin, the bloodiest battle fought in Korea during the Soviet-Japanese War for which he received Order of the Patriotic War 1st class, a military decoration awarded for heroic deeds on the battlefield. ${ }^{60} \mathrm{He}$ was also a battalion commissar before the institution of political commissars was abolished in 1942 and as such he most probably was a person with leadership and organisational skills who knew how to keep his subordinates in line. Such knowledge and skills were undoubtedly imperative for the head of the police department in the circumstances of liberated North Korea. Later Zagruzin would serve as the military advisor to the commander of the 2nd Infantry Division of the KPA. ${ }^{61}$

Structurally, the newly created PDNK was comprised of eight divisions, namely the public security division, criminal division, prison division, general affairs division, economic management division, human resources division, sanitary division and firefighting division. The first division whose full name was the "division for public order and tranquillity" was responsible for one of the most sensitive spheres of North Korea, that is, economic crimes (such illegal price manipulations), registration of local businesses, protection of the private, state and common property, etc. The second division was responsible for fighting and investigating crimes such as theft, robbery, murder, etc. The prison division was managing and guarding prisons. The general affairs division was responsible for record management and issuing passes, identifying documents to the civilian population for travelling purposes. The human resources division managed cadres. The economic division was responsible for the material condition of the police, including uniforms, salaries, etc. The sanitary division was created to deal with poor sanitary conditions on the streets and public places, as well as to control the storage and use of medication in North Korea. Finally, the firefighting division organised fire protection in the towns and cities of North Korea by providing firefighting equipment including trucks. ${ }^{62}$ It is also important to note that at that time, all political crimes were handled directly by the SMERSH of the 25th Army, and there was, therefore, no political section in the North Korean police.

Structurally the police system created by the Soviets in the first years of the occupation had three levels. At the lowest level, there were the police "sub-offices" ( poanbunsŏ). These sub-offices, which were located in villages and small towns, had a simple structure and were staffed by around 8-10 men. ${ }^{63}$ They were local agents of a higher-level county (kun poansŏ) or city (si poansŏ) police offices. Unlike sub-offices, whose role was just to execute orders, the police offices at a county level were the lowest North Korean police organisation with the power to command and manage the staff of lower organisations. Structurally, county police offices had six divisions including the divisions of public

\footnotetext{
${ }^{59}$ TsAMO F. USGASK, Op. 343253, D. 3, L. 28.

${ }^{60}$ TsAMO F. 33 , Op. 687572, D. 2570, L. 41.

${ }^{61}$ MORF 2020.

${ }^{62}$ TsAMO F. USGASK, Op. 343253, D. 3, L. 28-32.

${ }^{63}$ Ibid. L. 47.
} 
security, criminal police, fire division, economic division, records and personnel division. The staff size was limited to 75 men including the head of the office, his deputy and a personal secretary. ${ }^{64}$

County police offices were directly subordinate to the police departments of their respective provinces. Each of the five provincial police departments (to poanbu) in North Korea was also comprised of six divisions similar to the structure of county police offices. However, there were some differences. The most notable difference was the function of the personnel division which apart from dealing with staff-related matters was also responsible for training police officers. The criminal division of the provincial police departments had a section whose role was to gather statistical data on the number of convicts, an issue that was one of the biggest problems for the Soviets at that time. The economic department was also supplied with a section that managed "tools" such as weapons, uniforms, etc. The staff size was around 120 men. ${ }^{65}$ Every department (poanbu) and office (poansŏ) also had a law enforcement unit (kyŏngbidae) under its command. ${ }^{66}$

At the top of the North Korean police system was the PDNK (poanguk). Its main function was to organise and control police agencies all over North Korea, and thus it did not have any police units under its direct control. All organisation charts for these agencies were written in Russian, translated into Korean and implemented. ${ }^{67}$

One of the elements that deeply influenced the formation of the North Korean police system was the degree of corruption of the North Korean police. It is most vividly illustrated in a report filed by the head of SMERSH counterintelligence department of the 1st Far Eastern Front Major General Nikolai Anokhin to Colonel General Chistyakov and Major General Romanenko. According to the report, the inspection conducted on 19 October by SMERSH operatives showed that the Pyongyang police arrested almost twice as many Japanese as it did Koreans, while the number of political prisoners exceeded the number of ordinary criminals. Torture and other violent interrogation methods were widely used. The problem was so severe that the SMERSH department emphasised the necessity of banning police in North Korea from conducting political arrests until they were reorganised. ${ }^{68}$ The illegal arrests were obviously carried out by various political forces, both communists and their adversaries, who attempted to use the police in their political struggle. To remove the possibility of police being used in the political struggle - which by that time was fierce all over North Korea - the creators of the PDNK decided to take Anokhin's advice seriously and removed every mention of political crimes from the draft of the document thus limiting the sphere of police responsibility to "criminal elements (thieves, murderers, etc.)." ${ }^{69}$ During the first two years of the occupation, the investigation of political crimes was almost exclusively carried out by the SMERSH of the 25th Army.

After the last parts of the reorganisation plan were formulated, translated into Korean and sent to the police departments and local People's Committees, Ch'oe Yong-gŏn was to ensure that these new instructions were understood and followed correctly. On 11 November, he held a meeting with the chiefs of all the major police offices of Pyongyang. During the meeting, Ch'oe was relieved to learn that the number of people arrested on political charges had radically dropped to "about 10 in every office" ${ }^{30}$ from a staggering figure of over 350 a month earlier. ${ }^{71}$ Most arrested were murderers, thieves, pickpockets and those who committed armed robberies. He then stressed that "in order to proceed with the mission of getting rid of the remnants of the Japanese imperialism and reactionaries with the goal of constructing new Korea," it was imperative to remove them from the police first. Presumably, Ch'oe was talking about those who conducted illegal arrests, practised tortures and

\footnotetext{
${ }^{64}$ Ibid. L. 45.

${ }^{65}$ Ibid. L. 46.

${ }^{66}$ Kim Sŏn-ho 2012, p. 302.

${ }^{67}$ For all 1945 charts and orders on the PDNK, see: TsAMO F. USGASK, Op. 343253, D. 3, L. 45-47.

${ }^{68}$ TsAMO F. USGASK, Op. 343253, D. 3, L. 48-51.

${ }^{69}$ Ibid. L. 39.

${ }^{70}$ Ibid. L. 49.

${ }^{71}$ Ibid. L. 39.
} 
other means of pressure on suspects, as this was the way such practices were referred to in the official texts of the PDNK including the Order No. 1 signed by him on 5 November $1945 .{ }^{72}$ Naturally, the North Korean police officers used this opportunity to stress that "the Soviet forces' interference in administrative affairs is great and their hindrance (chijang) to [our] affairs is not small," and expressed their wish that "the police will have cooperation with the Soviet army."

Indeed, the results of the reforms were soon felt. After a check conducted at the end of 1945, the head of the Department of Police reported that over 2,000 prisoners were freed as illegally arrested. ${ }^{74}$ In the Soviet Civil Administration Directorate in North Korea (USGASK)'s final report in 1948, Soviet officers proudly stated that in November 1945 almost half of the prison population of northern Korea, which by that time numbered around 8,000 people, was freed. ${ }^{75}$

With the creation of the PDNK, the Soviets launched a personnel reorganisation campaign, which launched several waves of mass expulsions from the police, aimed at reducing corruption and weakening its connections with the political circles. For the purposes of the reorganisation campaign, Zagruzin proposed to create a commission in every province headed by the Soviet military representative of the given province, a representative of SMERSH and 3-5 Koreans who would represent various local social organisations. ${ }^{76}$

The first wave was completely conducted by the Soviets at the end of 1945 and it resulted in a great reduction of police staff. Zagruzin stated in his report, compiled at the end of December 1945, that as a result of the reduction in the management apparatus and laying off some "elements that stuck to the police” in some places, like South P'yŏngan province, almost $50 \%$ of staff were removed.

The campaign did not spare even the local leadership of the North Korean police. In NovemberDecember 1945, the Soviets removed two of the heads of provincial police departments, along with two deputy heads. ${ }^{77}$ The final report on the Soviet administration's activities states that by the end of November, around 3,800 men were purged from the police which amounted to $41.5 \%$ of the total number of policemen in North Korea. ${ }^{78}$ Moreover, in order to make it more difficult for the North Korean police to engage in political activities, the Soviets additionally decided to put the police under the supervision of the prosecutor offices which were also under the full control of the Soviet military administration. ${ }^{79}$

All these facts clearly demonstrate that the popular argument that after disbanding the former police agencies, the "Soviets selected 2,000 men whom they judged to be faithful followers of Communist ideology" for the new police is not supported by available documentary evidence.

De facto the degree of SMERSH involvement in North Korean affairs was even higher. It included not only control over purges in the police, fighting political crime, which at first mostly meant fighting anti-Soviet propaganda, abuse of authority for political and/or economic gain, etc. For the Soviets, it was also important to prevent North Koreans from engaging in activities that were deemed "unnecessary" by the Soviet military authorities. The best example of such activities was the incident with the "North Korean sunken ship recovery company (Pukchosŏn ch'imsu sŏnbak inyang kongsa)," which was created in 1946 by a group of "patriotic Korean entrepreneurs with the goal to recover goods and ships from the bottom of the sea." The SMERSH of the 25th Army apparently decided that the works of the given company were connected with a Korean attempt to build a navy of their own. The company's equipment was promptly confiscated, forcing Kim Il-sung to write a complaint to military authorities. ${ }^{80}$

\footnotetext{
${ }^{72}$ Ibid. L. 1-3.

${ }^{73}$ Ibid. L. 43-44.

${ }^{74}$ Ibid. D. 9, L. 142ob.

${ }^{75}$ AVPRF F. 0480, Op. 4, P. 14, D. 46, L. 250.

${ }^{76}$ TsAMO F. USGASK, Op. 343253, D. 9, L. 143.

${ }^{77}$ Ibid. L. 226ob.

${ }^{78}$ AVPRF F. 0480 , Op. 4, P. 14, D. 46, L. 249-250.

${ }^{79}$ TsAMO F. USGASK, Op. 343253, D. 2 L. 31.

${ }^{80}$ TsAMO F. 142 , Op. 432241s, D. 3, L. 8-13.
} 
Though the implementation of the new instructions did not meet any open opposition, to the Soviets' surprise, this was not the case with the name of the new police organisation. It seems that the North Koreans were ready to accept new methods of maintaining public order, but they were completely intransigent over the Soviet-imposed nomenclature.

Stalin's directive made it clear that the Soviet military administration was to assist the "establishment of a bourgeois-democratic state" and should not install any Soviet institutions. In Soviet ideology, the police agencies were perceived as a tool of the ruling bourgeois class in contrast to the Soviet police which was named "militia (militsiya)," representing the armed people (vooryzhennyi narod). The directives from Moscow were clear, and soon after that Soviets proclaimed the creation of the North Korean police (politsiya).

The order to create the police force was sent in mid-November to all military commandants along with the "Order No. 1 of the Head of the Police Department of North Korea." The order was supplemented with original Russian documents whose Korean translations were sent separately through the PDNK channels. ${ }^{81}$

Though both the order and supplementary Soviet documents clearly stated that the new structure was to be called "police," the Korean translation of the same documents done by the translators of the PDNK creatively translated the Russian word “politsiya” as “poan” (lit. peacekeeping [force]) 保安 instead of traditional “kyŏngch'al” 警察. ${ }^{82}$ Most probably, the Koreans responsible for translating the documents did so without proper supervision from the Soviet authorities, who had a great shortage of Korean translators during their first months of occupation and were, therefore, unable to control the precision with which their orders were transmitted. ${ }^{83}$ The problem was that the word "kyongch'al" was detested by Koreans, especially by the left-wing nationalists, who associated it with the Japanese military police (kempeitai).

This terminological inconsistency was soon discovered by military commandants all over North Korea. It clearly was a breach of both Stalin's directive and the Order No. 7, so the Soviet military officials immediately launched a war on this term. In some cases, the measures taken by the Soviet commandants consisted of verbal warnings and complaints to the high-level authorities. ${ }^{84}$ In other cases, commandants were confiscating all armbands and signboards that did not have "police," i.e. kyŏngch'al, written on them and ordered the use of other terms than kyŏngch'al to be abandoned. ${ }^{85}$

Much to the Soviets' surprise, North Koreans were adamant about their terminology and refused to change it even on direct orders from the Soviet military command. It is a historical fact that the Soviets finally gave in and decided to effectively ignore the Korean terminology as long as it did not appear in their documentation, where they kept using the word "politsiya."

Currently, there is no documentary evidence that could shed light on the reasons why the Soviets agreed to do this, but according to the recollections of Pak Kil-yong, one of the Soviet high-level interpreters, Cho Man-sik, one of the North Korean political leaders in Pyongyang, had a debate with Zagruzin, asking him not to use the word "police," but Zagruzin refused to change it. Cho then went to the Soviet Korean interpreters asking whether the word police in the "Soviet language (soryŏn-б)" could be translated as "poan" and, when the interpreters finally agreed that this was theoretically possible, Cho went directly to Romanenko and persistently asked him to allow Koreans to

\footnotetext{
${ }^{81}$ TsAMO F. USGASK, Op. 343253, D. 3, L. 1.

${ }^{82}$ Ibid. L. 33-38.

${ }^{83}$ Lack of competent and professional translators plagued Soviet work in Korea for almost entire period of occupation, but it was especially severe during the first year. For example, the Military representative to Kangwondo province Lieutenant Colonel Soloviev in his report written 17 December 1945 stated that "local interpreters always interpreted everything in a way to show that both party organisation and People's committees were in perfect order." TsAMO F. USGASK, Op. 343254, D. 2, L. 128ob.

${ }^{84}$ TsAMO F. USGASK, Op. 343253, D. 9, L. 94.

${ }^{85}$ Ibid. L. 48-48ob.
} 
use the word "poan." ${ }^{86}$ Analysis of available Soviet documents shows that after two months of debating, around late December 1945 the Koreans were finally permitted to keep the name.

\section{Conclusion}

Careful examination of the available Soviet archival evidence shows that the early history of North Korean police fits neither the Kim Il-sung-centred nor North Korean elite-centred narrative that is popular among some modern South Korean scholars, nor does it fit the narrative that portrays Soviet actions as a deliberate "sovietisation" from the very beginning of the occupation. ${ }^{87}$ The actions of the Soviet military government during the first months of the occupation were directed at fighting the local criminal activity and political violence (including terrorism) in North Korea, a typical phenomenon during a vacuum of power, as well as the crimes committed by some soldiers of the Red Army.

The activities of the Communist Party in Korea during the initial stage of occupation by no means presented them to the Soviets as trustworthy allies. The factional struggle on all levels, which even included the publication of a fake Soviet document, low theoretical level of the communist cadres also contributed to the image of Korean political groups in the eyes of the Soviet administration. Thus the argument that the creation of North Korean police manifested the desire of the Soviets to cooperate with North Korean communists and give them exclusive "right to [create] an army 軍權” from the beginning of the occupation is also not supported by the available evidence.

What is usually overlooked, however, is the influence of the processes that were set in motion by the brief Soviet-Japanese war. The Manchurian Strategic Offensive Operation and its effect on the Korean peninsula as seen by the Soviets deserve a more profound investigation. This requires additional work in the Russian archives, most importantly TsAMO (the Russian Military archive) that according to what the author has learned by working with the documents still holds a large amount of both Army-level and Division-level documents that would most certainly improve our understanding of the Soviet policy towards early North Korea.

\section{References}

\section{Primary sources}

In Korean:

Kuksa p'yŏnch'an wiwŏnhoe (National Institute of Korean History; NIKH) (1990). Pukhan kwangye saryojip. (Collection of Historical Materials on North Korea), Vol. 9. Kwach'ŏn: NIKH.

\section{In Russian:}

Ministerstvo Oborony Rossiiskoi Federatsii Министрество обороны Российской Федерации. (Ministry of Defence of Russian Federation; MORF) (2020). “Zagruzin Nikolai Yakovlevich.” https://foto.pamyat-naroda.ru/detail/2263099?static_hash $=1 \mathrm{clf}$ cacde4bf5872d6b2b70af1cfdf24

Tsentral'niy Arhiv Ministerstva Oborony Центральный архив Министерства Обороны (Central Archives of the Russian Ministry of Defence; TsAMO). F. 142, Op. 432241s, D. 3. "Sekretariat komanduyushego voiskami Prim. VO. Perepiska po voprosam Korei.” Секретариат командующего войсками Прим. ВО. Переписка по вопросам Кореи. (“Secretary of the commander of Primorsky Military District. Correspondence on Korea.").

TsAMO F. 172, Op. 614630, D. 5. "Sekretariat komanduyushego voiskami Prim. VO. Delo №. 5. Dokumenty harakterizuyushiye politicheskiye partii I obshestvenniye organizatsii Severnoi Korei za 1945 god” Секретариат командующего войсками Прим. ВО. Дело №5. Документы характеризующие политические партии и общественные организации Северной Кореи за 1945 год. (“Secretary of the commander of Primorsky Military District. Folder No. 5. Documents characterising political parties and social organisations of North Korea in 1945.”).

\footnotetext{
${ }^{86}$ Kim Guk-hu 2013, p. 41.

${ }^{87}$ For example, see Chang Jun-ik 1991, p. 95.
} 
TsAMO F. 234, Op. 3213, D. 126, L. 131-132. “Prikaz komanduyushemu 25-i Armiyei.” Приказ командующему 25 Армией. ("Order to the commander of the 25th Army").

TsAMO F. 32, Op. 11318, D. 196. "Glavnoe politupravlenie. Otdel po obobshheniju opyta partpolitraboty. PU 1-go Dal'nevostochnogo fronta. Delo 8/28 ch. II. Prilozhenie k dokladu. Listovki, plakaty, lozungi dlja vojsk protivnika i naselenija Man'chzhurii i Korei.” Главное политуправление. Отдел по обобщению опыта партполитработы. ПУ 1-го Дальневосточного фронта. Дело 8/28 ч. II. Приложение к докладу. Листовки, плакаты, лозунги для войск противника и населения Маньчжурии и Кореи. (“Main political directorate. Department for generalizing the experience of party and political work. Political directorate of the 1st Far-Eastern Front. Folder 8/28 part 2. Attachment to the report. Leaflets, posters, slogans for the enemy troops and the population of Manchuria and Korea").

TsAMO F. 33, Op. 687572, D. 2570. "Nagradnye listy." Наградные листы. (“Documents on medal awards").

TsAMO F. USGASK, Op. 102038, D. 1. "MVS SSSR. Upravlenie Sovetskoj Grazhdanskoj Administracii v Severnoj Koree. 1946g. Doneseniya voennyh komendatur” МВC СССР. Управление Советской Гражданской Администрации в Северной Корее. 1946 г. Донесения военных комендатур. ("Ministry of the Military Forces of the USSR. The Directorate of Soviet Civil Administration in North Korea. 1946. Reports of the military commandants.").

TsAMO F. USGASK, Op. 102038, D. 2. "MVS SSSR. Upravlenie Sovetskoi Grazhdanskoi Administratsii v Severnoi Koree. 1946g. Doneseniya i spravki o nastroyeniyah naseleniya Severnoi Korei” MВС СССР. Управление Советской Гражданской Администрации в Северной Корее. 1946 г. Донесения и справки о настроениях населения Северной Кореи. ("Ministry of the Military Forces of the USSR. The Directorate of Soviet Civil Administration in North Korea. 1946. Reports and information concerning the sentiments of the population of North Korea.").

TsAMO F. USGASK, Op. 343253, D. 2. "MVS SSSR. Upravlenie Sovetskoi Grazhdanskoi Administratsii v Severnoi Koree. 1945g. № 17. Perepiska po departamentu yustitsii” MBC СССР. Управление Советской Гражданской Администрации в Северной Кореe. 1945 г. № 17. Переписка по департаменту юстиции. (“Ministry of the Military Forces of the USSR. The Directorate of Soviet Civil Administration in North Korea. 1945. No. 17. Correspondence of the Department of Justice.").

TsAMO F. USGASK, Op. 343253, D. 3. “MVS SSSR. Sovetskoi Grazhdanskoi Administratsii v Severnoj Koree. $1945 \mathrm{~g}$. № 18. Perepiska po departamentu politsii” МВC СССР. Управление Советской Гражданской Администрации в Северной Кореe. 1945 г. № 18. Переписка по департаменту полиции. (“Ministry of the Military Forces of the USSR. The Directorate of Soviet Civil Administration in North Korea. 1945. No. 18. Correspondence of the Department of Police.").

TsAMO F. USGASK, Op. 343253, D. 9. "MVS SSSR. Upravlenie Sovetskoi Grazhdanskoi Administratsii v Severnoj Koree. 1945g. № 033. Doneseniya voennyh komendatur” МВС СССР. Управление Советской Гражданской Администрации в Северной Корее. 1945 г. № 033. Донесения военных комендатур. (“Ministry of the Military Forces of the USSR. The Directorate of Soviet Civil Administration in North Korea. 1945. No. 033. Reports of the military commandants.").

TsAMO F. USGASK, Op. 343254, D. 2. "MVS SSSR. Upravlenie Sovetskoi Grazhdanskoi Administratsii v Severnoj Koree. 1945-46 gg. № 022. Donesenija voennyh komendatur o politiko-moral'nom sostoyanii mestnogo naseleniya” MBC СССР. Управление Советской Гражданской Администрации в Северной Корее. 1945-46 гг. № 022. Донесения военных комендатур о политико-моральном состоянии местного населения. ("Ministry of the Military Forces of the USSR. The Directorate of Soviet Civil Administration in North Korea. 1945-1946. No. 022. Reports of the military commandants on the political and moral sentiments of the local population.").

TsAMO F. USGASK, Op. 433847, D. 1.

TsAMO F. Voyennoi komendatury provintsii Phenyan-pukto, Военной комендатуры Пхеньян-Пукто (Military commandant office of the Pyongyang-pukto province), Op. 536317, D. 19.

Arhiv Vneshnei Politiki Rossiiskoi Federatsii Архив Внешней политики Российской Федерации (Foreign Policy Archives of the Russian Feredation; AVPRF) F. 0102, Op. 1, P. 1, D. 5.

AVPRF F. 0480, Op. 2, P. 2, D. 7.

AVPRF F. 0480, Op. 4, P. 14, D. 46. "Doklad ob itogah raboty Upravleniya Sovetskoi Grazhdanskoi Administratsii v Severnoi Koree za tri goda. (Avgust 1945g. - nojabr’ 1948g.) Tom I. Politicheskaja chast'. G. Phen’yan, dekabr’ 1948.” Доклад об итогах работы Управления Советской Гражданской Администрации в Северной Корее за три года. (Август 1945 г. - ноябрь 1948 г.) Том І. Политическая часть. г. Пхеньян, декабрь 1948. ("Report on the results of the work of the Directorate of Soviet Civil Administration in North Korea over three years. (August 1945 - November 1948). Volume 1. Political section. Pyongyang, December 1948.”).

AVPRF F. 0480, Op. 4, P. 14, D. 47. "Doklad ob itogah raboty Upravleniya Sovetskoi Grazhdanskoi Administratsii v Severnoi Koree za tri goda. (Avgust 1945g. - nojabr’ 1948g.) Tom II. Ekonomicheskaya chast'. G. Phen'yan, dekabr’ 1948.” Доклад об итогах работы Управления Советской Гражданской Администрации в Северной Корее за три года. (Август 1945 г. - ноябрь 1948 г.) Том II. Экономическая часть. г. Пхеньян, декабрь 1948. ("Report on the results of the work of the Directorate of Soviet Civil Administration in North Korea over three years. (August 1945 - November 1948). Volume 2. Economic section. Pyongyang, December 1948.”).

Rossiskii Gosudarstvennii Arhiv Sotsial'no-politicheskoi Istorii Российский государственный архив социальнополитической истории (Russian State Archive of Socio-Political History; RGASPI). F. 17, Op. 128, D. 47, L. 2-3. 
“Kratkij informacionnyj doklad o polozhenii v Koree.” Краткий информационный доклад о положении в Корее. ("Brief report on the situation in North Korea").

\section{Secondary sources}

Armstrong, C. K. (2003). The North Korean Revolution, 1945-1950. Ithaca: Cornell University Press.

Chang Jun-ik 張浚翼 (1991). Pukhan Inmingundaesa 北韓人民軍隊史 (History of North Korean People's Army). Seoul: Sŏmundang.

Chistyakov I. М. Чистяков И.М. (1975). “Sluzhim otchizne” Служим отчизне (We Serve the Fatherland). Moscow: Voyenizdat.

Chŏn, Hyŏn-su 전현수 (1995). “Soryŏngunŭi pukhan chinjuwa taebukhan chŏngch'aek" 소련군의 북한 진주와 대북한정책 (Soviet Union Army's stationing in North Korea and its policy towards North Korea). Hanguk tongnip undongsa yŏngu 한국독립운동사연구 (Journal of Korean Independence Movement Studies) 9, pp. 343-77.

Cumings, B. (1981). Liberation and the Emergence of Separate Regimes, 1945-1947. Princeton, NJ: Princeton University Press.

Cumings, B. (1990). The Roaring of the Cataract, 1947-1950. Princeton: Princeton University Press.

Glantz, D. M. (2003). The Soviet Strategic Offensive in Manchuria, 1945: August Storm. London; Portland, OR: Frank Cass.

Han, Hong-sŏk 한홍석 (2002). Ijenŭn marhal su itta. Che 45 hoe - Pimil kyŏlsa Paegŭisa 이제는 말할 수 있다. 제 46 회 비밀결사 백의사 (We can speak now. Part 46 - Secret organisation Paegŭisa), MBC. Accessed 18 September 2020. www. youtube.com/watch?v = lk6H-ESFXhY

Khristoforov, V. S., Христофоров В. С., Vinogradov V. К., Виноградов В. К., Matveev О. К., Матвеев О. К. еd. (2010). "SMERSH: Istoricheskiye ocherki i arkhivniye dokumenty" «Смери»: Исторические очерки и архивные документы. (SMERSH: Historical Overview and Archival Documents). Moscow: Moskovskie uchebniki I kartografiya.

Ki Gwang-š 奇光舒 (2004). "Pukhan myrŏk hyŏngsŏnggwa puk-so kwangye 북한 무력 형성과 북소관계 (Formation of North Korea's Military and the North Korean-Soviet Relations).” Chungso yŏngu 中蘇研究 (Sino-Soviet Affairs) 103, pp. 215-34.

Kim, S. (2013). Everyday Life in the North Korean Revolution, 1945-1950. Ithaca: Cornell University Press.

Kim, Y. (2018). Origins of the North Korean Garrison State: The People's Army and the Korean War. London; New York: Routledge, Taylor \& Francis Group.

Kim Gi-sŏk 김기석 (1947). Pukchosŏnŭi hyŏnsanggwa changnae 북조선의 현상과 장래 (Current State and Future of North Korea). Seoul: Chosŏn chŏnggyŏng yŏngusa.

Kim Guk-hu 김국후 (2013). Pyŏngyangŭi k'areisk'I ellit'ŭdŭl 평양의 카레이스키 엘리트들 (Soviet Korean Elites of Pyongyang). P’aju: Hanul.

Kim Gwang-un 김광운 (2003). Pukhan chŏngch'isa yŏngu 북한정치사연구 I (Research of North Korean Political History Vol. 1). Seoul: Sŏnin ch'ulp'ansa.

Kim Gwang-un 김광운 (2018). Puk Chosŏn Sillok. Nyŏnp'yowa saryo 북조선실록. 년표와 사료. (Veritable Records of North Korea. Timeline and Documents, Vol. 1). Seoul: Korea Data Project.

Kim Sŏn-ho 김선호 (2012). "Haebang chikhu Pukhan Poangukui chojikkwa hwaltong 해방직후 북한 보안국의 조직과 활동 (Organisation and activities of North Korean Security Bureau after the liberation).” Yŏksawa hyŏnsil 역사와 현실 (History and Reality) 86, pp. 293-324

Kim Sŏn-ho 김선호 (2016). Chosŏn Inmingun yŏngu 조선인민군연구 (Study of the Korean People's Army), Kyŏnghŭi University Graduate School, Doctoral dissertation.

Kim Sŏn-ho 김선호 (2020). Chosŏn Inmingun: Pukhan myrŏkŭi hyŏngsŏnggwa yuilch'ejeŭi kiwŏn 조선인민군: 북한 무력의 형성과 유일체제의 기원 (Korean People's Army: The Making of North Korean Army and the Origin of the Kim Il-sung's Regime). Seoul: Hanyangdae ch'ulp'anbu.

Kukpangbu Kunsap'yŏnch'anyŏnguso 국방부 군사편찬연구소 (Institute for Military History of Ministry of National Defence of the Republic of Korea; IMHMND) (2004). 6.25 chŏnjaengsa 1: chŏnjaengŭi paegyŏnggwa wŏnin $6 \cdot 25$ 전쟁사 1: 전쟁의 배경과 원인 (The History of Korean War 1: Background and the Reasons of the War), Vol. 1. Seoul: IMHMND.

Lan'kov, A. N. (2002). From Stalin to Kim Il Sung: The Formation of North Korea, 1945-1960. New Brunswick, NJ: Rutgers University Press.

MBC Bureau of Current Affairs and Production 문화방송 시사제작국 (2002). MBC t'ŭkpyŏl kihoek. Ijenŭn malhal su itta. 2002 nyŏn. 46 hoe - Pimil kyŏlsa Paegŭisa MBC특별기획 이제는 말할 수 있다. 2002년. 46회 - 비밀결사 白衣社 (MBC Special program. We can speak now. Part 46 - Secret organisation Paegŭisa). Munhwa pangsong Sisachejakkuk.

Ree, E. V. (1989). Socialism in One Zone: Stalin's Policy in Korea, 1945-1947. Oxford England; New York: Berg.

Ternovsky, G. V., Терновский Г. В. (1965). “Osvobozhdenie portov Severnoi Korei Освобождение портов Северной Кореи (The Liberation of North Korean Ports).” In “Vo imya druzhby s narodom Korei” Во имя дружбы с народом Кореи (In the Name of Friendship with the People of Korea), ed. Ivanova V. I., Иванова В. И., Lebedev N. G., Лебедев Н. Г., Наn М. Үu., Хан М. Ю., Shabshina F. І., Шабшина Ф. И. Moscow: Nauka. pp. 90-118. 
To Jin-sun 도진순 (1997). Hanguk minjokjuiwa Nambukkwangye - I Sŭngman, Kim Gu sidaeŭi Chŏngch'isa 한국민족주의와 남북관계 - 이승만 - 김구 시대의 정치사 (Korean Nationalism and North-South Relationship Political History of the Era of Lee Sŭng-man and Kim Gu). Seoul: Seoul National University Press.

Yi Ju-hwan 이주환 (1998). Chosŏngongsandangŭi rosŏn taerip yŏngu: haebang chikhurŭl chungsimŭro 朝鮮共産黨의 路線 對立研究: 解放直後를 中心으로 (Study of conflict of Lines of the Korean Communist Party: Focusing on the period immediately after the liberation), Graduate School of Tongguk university, Master's thesis.

Yi Wan-bŏm 李完範 (1991). "Pukhan chŏmnyŏng Soryŏngunŭi Sŏngkyŏk 북한 점령 소련군의 성격 (The Character of Soviet Military Occupation of North Korea).” Kuksagwan Nonchong (국사관논총) 25, pp. 160-81.

Cite this article: Lebedev V (2022). War and peace in liberated North Korea: Soviet military administration and the creation of North Korean police force in 1945. International Journal of Asian Studies 19, 117-133. https://doi.org/10.1017/ S1479591421000127 